\title{
Leading Learning: A Grounded Theory Perspective of the Orang Asli Students' Learning Journey
}

\author{
Misnaton Rabahi, Hamidah Yusof*, Marinah Awang
}

Department of Management \& Leadership, Faculty of Management \& Economics, Universiti Pendidikan Sultan Idris, 35900 Tanjung Malim, Malaysia

*Corresponding author: hamidah.yusof@fpe.upsi.edu.my.

\begin{abstract}
Past research on the indigenous Orang Asli education highlights the various factors that contributed to the Orang Asli students' learning disengagement and poor achievement in school, both primary and secondary. This paper presents a grounded theory perspective that illuminates the learning journey of Orang Asli students who have reached higher education despite the oft cited challenges and barriers. Sixteen Orang Asli students shared the experience of their early years, and of school, through in-depth unstructured interviews. Sampling was purposeful, within the context of theoretical sampling following the Grounded Theory method. Constant comparative analysis reveals an emerging theory of leading learning in the education of Orang Asli students. Implication for practice includes for stakeholders to consider the Orang Asli's strengths, as well as the social and cultural capital in leading the learning of the community's children. Leveraging on their strengths and continuous improvement will contribute to the sustainability of the Orang Asli education, and the thriving of the community. This study is valuable as it refers to aspects of Orang Asli education that have not been sufficiently illuminated in the existing literature and discussion on the topic, except in the context of a deficit. It contributes to the body of literature that supports hope and achievement for the minority, indigenous community, despite the deficit.
\end{abstract}

Keywords: Leading learning; grounded theory; Orang Asli research; personal agency; strength-based practice

\begin{abstract}
Abstrak
Kajian lepas menonjolkan pelbagai faktor yang melonggarkan ikatan pembelajaran pelajar Orang Asli di peringkat sekolah rendah juga menengah. Menggunakan perspektif Grounded Theory, artikel ini mengetengahkan teori yang terhasil dari perjalanan enam belas (16) orang pelajar Orang Asli yang telah berjaya ke institusi pengajian tinggi dalam negara. Teori tentang bagaimana mereka bertahan dalam keadaan defisit kehidupan. Kajian menggunakan persampelan bertujuan dan persampelan teoretikal. Data pula dikumpul melalui temu bual tidak berstruktur yang mendalam dan terperinci. Dari analisis perbandingan yang berterusan (Constant Comparative Method), muncul teori meneraju pembelajaran di kalangan pelajar Orang Asli. Implikasi kepada praktis termasuk untuk pihak yang berkepentingan mempertimbangkan kekuatan Orang Asli, modal social serta budaya mereka dalam menerajui pembelajaran kanak-kanak masyarakat tersebut. Memanfaatkan kekuatan dan penambahbaikan berterusan akan menyumbang kepada kelestarian pendidikan dan pembangunan masyarakat Orang Asli. Kajian ini merujuk kepada aspek-aspek pendidikan Orang Asli yang kurang dibincangkan dalam literatur sedia ada, kecuali dalam konteks defisit. Ia menyumbang kepada badan ilmu yang memberi harapan kepada pencapaian masyarakat peribumi, meskipun dalam keadaan defisit.
\end{abstract}

Kata kunci: Meneraju pembelajaran; grounded theory; kajian Orang Asli; agensi kendiri; amalan berasaskan kekuatan

(C) 2017 Penerbit UTM Press. All rights reserved

\subsection{INTRODUCTION}

Being poor and in the margin appear to be conducive ingredients for poor academic achievement. Indeed, this is the prevalent deficit model in education that rationalises the lack of achievement among disadvantaged students, worldwide. This model sees diversity in lifestyle, language, ways of learning, as problematic and views the deficiencies of poor, and minority group students, their families and communities as the main causes of students' school problems and academic failure (Valencia, 1997, 2010).

After a long standing deficit theorizing, Canada learned that their current education system does not work for many students and this includes the need of the nation's aboriginal learners (Oberg, Blades \& Thorn, 2007; Berryman et al., 2014). The state of the indigenous education remains, as reviewed by Berryman et al. (2014), a failure to implement the long-standing appropriate research-based findings to improve learning outcomes, with the authors suggesting that the underlying reason is related to a perspective by the dominant western society that the best solution for the indigenous people was assimilation. The authors argue that poor learning outcomes are due to the effects of poverty, racism, and attitudes of colonization.

Australia has similar concerns with the academic achievement of the Australian indigenous population (Helme \& Lamb, 2011; Ford, 2013; Guenther, 2015). Ford (2013) argues that results continue to show very poor educational outcomes for indigenous students" (p.81), whilst Guenther (2015) highlights concerns pertaining to very remote Aboriginal education that includes closing the achievement gap, low attendance rate and low levels of academic performance. 
In New Zealand, concerns of learning disengagement and low attainment among the indigenous Maori students triggered a decade long research for its resolution. Through the research, students contributed their narratives that debunked prevalent myths about their educational aspirations and those of their parents, as explanations of problems facing Maori student's achievement (Bishop, Berryman, Tiakiwai \& Richardson, 2003). Since then, the government has documented the concerted educational efforts to accelerate the success of the indigenous Maori population (MOENZ, 2013).

The case of Malaysia's indigenous Orang Asli students is no exception. Orang Asli is the official name of the Peninsular Malaysia indigenous community representing about 0.6 percent (178,197 at 2013 as cited in JAKOA, 2015a) of the total population. They comprise diverse groups of 18 indigenous ethnic tribes, distinguished by their respective ethnic languages and social-cultural identities (Lye, 2011; Tarmiji, Fujimaki \& Norhasimah, 2013, JAKOA, 2015b). Their social and economic position situates them among the disadvantaged minorities, the majority living beneath the poverty line (Mohd Asri, 2012) and marginalised (Johari \& Nazri, 2007; Tarmiji, Fujimaki \& Norhasimah, 2013). Historically, the Orang Asli education was formalized in 1952 (Edo, 2012). Since then, educating the community has been one of the Government's priorities (MOE, 2013; News, 2015a, 2015c).

However, educational attainment of the Orang Asli has been problematic (Wan Afizi, Shaharuddin \& Noraziah, 2014; SUHAKAM, 2015; Norwaliza, Ramlee \& Abdul Razaq, 2016). Moreover, past research revealed a similar deficit model reflected in the desire to explain underachievement and learning disengagements among the Orang Asli students. The reasons included lack of interest in schooling, attitude, poverty, implementation failure, accessibility, parental involvement, curriculum, pedagogical skills, the quality of leadership of school administrators, the school climate, and social-cultural milieu of the Orang Asli society (Kamaruddin \& Jusoh, 2008; Sharifah, et al., 2011; Mohd Asri, 2012; Ramle, Wan Hasmah, Amir Zal \& Asmawi, 2013; Ramlee, 2013). In a study of literacy level of aboriginal students, Ramlah \& Aslina (2013) concluded that psychosocial problems identified as family environment, low family income, mother tongue language, cognitive ability, curriculum and the Orang Asli culture, hinder the Orang Asli students from going to school.

In contrast to the deficit model, Ladson-Billings (1995), Nelson (2002) and Bishop et al. (2011) presented an anti-deficit thinking in educating the disadvantaged minority and indigenous students. They challenge teachers to identify and examine existing belief about their students, embrace the opportunity to effect change, believe that they can and know how to make a difference, build relationship with, and build self-belief in the students.

This paper presents the findings from a grounded theory study that takes its cue from the anti-deficit thinkers and challenges the notion of deficit as a barrier to achievement. Findings are based upon the data shared by sixteen (16) Orang Asli participants who have reached the tertiary level of education. Retrospective perspective on their schooling years provides glimpses of how learners developed ownership of their learning. The study captures the learners' voices and presents aspects of Orang Asli students' learning process that have not been sufficiently illuminated in the existing literature and discussion on the topic, except in the context of deficit theorizing.

\subsection{THEORETICAL CONSIDERATIONS}

The established role of the literature review in Classic Grounded Theory method (CGT) is to provide additional data for constant comparison (Glaser \& Strauss, 1967; Glaser \& Holton, 2004). Thus, data from the major literature review of emerging concepts are weaved into the findings. However, following Hoda (2011), an initial minor literature review was conducted that contributed to the methodological understanding and theoretical sensitivity. It brought the historical context and the issues associated with the Orang Asli students' learning disengagement and poor academic achievement into perspective. The subsequent major literature review sought extant literature in the substantive area based upon emerging concepts and hypotheses during the constant comparative analysis. Although the CGT's dictum is to enter the field with no pre-conception (Glaser, 2012), still the motivation for the research was contained within the practice and theoretical lens of quality management with respect to continuous improvement in education (Misnaton, 2001; Misnaton, Hamidah \& Marinah, 2015a). The lens and CGT provided the optimism to search in an area that has been well-researched, yet remains unquenched.

\subsection{METHODOLOGICAL CONSIDERATIONS}

The triggering consideration for the methodology used was the exploratory nature of the issue. The intent was to generate a path of understanding which would not be effective, "when people bring their preconceptions into an interaction and speak from a place of already knowing instead of engaging with openness, a desire to learn, and respect for what might emerge (Oberg, Blades \& Thom, 2007, p.134)". Glaser's CGT method (Glaser \& Strauss, 1967) was deemed the most appropriate to explore the 'what contributed' to the sustained schooling of some students among these Orang Asli children despite their deficit conditions.

The research participants comprised sixteen Orang Asli tertiary level students and graduates aged 18 to 25 years old from a total of eight public higher education institutions in the country. Their ethnic tribes were Jakun (4), Semai (3), Jah Hut (6), and Temuan (3), whilst their highest educational qualifications were bachelor degree (3), diploma (1), bachelor degree-in-progress (8), and diploma-in-progress (4), in various disciplines of science and technology (12), and arts and humanities (4). The initial data collection was purposive and exploratory in order to give direction to the research. This included telephone conversations with officials of the Department of Orang Asli Development, also referred to as Jabatan Kemajuan Orang Asli (JAKOA), visits to a State JAKOA office and its headquarters, conversations with the JAKOA officers, visits to an Orang Asli Primary School and an Orang Asli village, conversations with the school administrator and teachers, and classroom visits. Following Glaser's 'no-preconception' and to 'just do it' (Glaser, 2012), further data was collected through two sessions of in-depth unstructured recorded interviews with the first student participant. Each interview session, conducted on different days, lasted about two hours. The questions, probes and prompts revolved around the experience of the student during her early years through her kindergarten, and primary schooling years. Guided by the emerging themes from the first stage data, theoretical sampling follows. Subsequent data were collected through recorded in-depth unstructured interviews of about two hours each, with more student participants, introduced through snowball leads. Free flow conversations and open questions such as, 'tell me about your 
life before kindergarten' promoted trust. Open ended probes led to more impromptu 'tell me more about that' type of questions in order to extract further details, especially when the initial question only elicited a one-word, one-liner response.

Data analysis was carried out using the constant comparative method that includes open coding, selective coding, memoing and reviews of the emerging relevant literature. Writing-up involved the sorting, shuffling and ordering of memos into a comprehensible output. The concurrent data collection and analysis are terminated upon saturation of concepts and categories, which means that subsequent data does not produce any new incident (Glaser \& Strauss, 1967).

\subsection{FINDINGS}

In its entirety, the data gathered reflects the concerns of parents, students, schools and significant others in the schooling process of the Orang Asli students. These concerns are discerned through the incidents narrated during the in-depth interviews, field visits and review of the literature. For instance, through their actions and provisions, it can be concluded that parents were concerned about their real life economic deficits and the future of their children. Their concerns were resolved through efforts to communicate the value of education to the children, and within their means and abilities, they provided the home support, provisions and routines that sustained the schooling of their children (Misnaton, Hamidah \& Marinah, 2015b).

Students were concerned about their parents' difficulties and hardships, and how the difficult life delimited their provisions. In addition, they were concerned about meeting the expectations of their parents and schools. The data revealed actions and behaviours that reflect the resolutions of their concerns. Their actions showed academic valuing, sharing their parents' belief and values of education as the means to pull them out of their dire life situation. They accepted punishments as part of the learning process, when they were not meeting the expectations of their parents and teachers. They envisioned their future individual self through their aims and ambitions; whilst, their changing aspirations indicate an awareness of their achievement, interest and potentials. The following sections elaborate the emerging findings of what concerns the students and how these concerns were resolved through the process of leading learning, which is the focus of this paper. This paper celebrates the multilingual context of the study, and the learners' voices through authentic texts.

\section{Learners Leading Learning}

Learners leading learning describes the emergent theory of Orang Asli students taking ownership of their learning process, before and during kindergarten, and through their primary schooling. It describes what contributed to the sustained learning engagement of the students based upon the abstraction of their experiences, conceptualized as initialising learning, facilitating learning, accommodating learning and generating learning. The process is about learners playing a part in their self-development, adaptation and self-renewal within the limits of their community's social, economic and cultural capitals.

\section{Initialising Learning}

The concept 'initialising' is similar to that used in computing, which is to set the value or put in the condition appropriate to the start of an operation. However, in this study, the 'value' refers to the motivating concepts arising from the students' interactions with and observations of their parents' adversities at home and real life routines. Bezzina (2012) refers to values as concepts that have motivating force and capacity to shape behaviours. Initialising learning is indicated through: experiencing hardships and poverty, parental aspiration, simply starts at home, and learning initiators.

Hardships and poverty were powerful motivators for education, and parents transferred their aspirations and visions of options to their children, whether to have a better future or to remain in hardships and poverty. Observing parents' trials and tribulations planted the resolve for educating self to help the family pulled out of dire poverty, as described by one participant who recalled her mother's tears upon returning from a neighbour's house, to borrow some household need, during which some harsh words were uttered.

Simple starts at home included reciting the alphabet song, interactions with older schooling siblings and friends. Parents, older siblings or friends set the eagerness in the children to experience kindergarten and school. Learning initiators included older friends roleplaying as teachers, conducting 'classes' for the younger school-going and non-school going children and playing traditional outdoor games that provided opportunities to learn by imitation. Through these games, they conceptualized school in Main Cikgu-cikgu (Playing Teacher), family life in Main Abah-Emak-Anak (Playing Father-Mother-Child) and Main Kawin-kawin (Wedding). They experienced early numeracy in Main Batu Seremban, as well as organizing, resourcing, problem-solving and strategizing skills in the various games. Rosenberg (1996), Fraser (2005) and Gill (2012) describe how traditional outdoor games provided children the opportunities for language development, thinking, problem solving, negotiating and a developing sense of fair play, and children's developing resourcefulness in building technology skills. Thus, home real life situations, parental aspirations, and real life activities with friends, set and shaped the children's starting self-concept as learners and expectations, as individuals as well as social beings, providing the initialising process towards formal institutionalised.

\section{Facilitating Learning}

The process of facilitating connotes behaviours and activities that promote, assist and support a process (Robinson, Molenda \& Rezabek, 2008). Facilitating learning in this study involves creating the means and conditions to promote, assist and support the continuity of learning and learning engagement (Misnaton, Hamidah \& Marinah, 2015b). From the learners' perspective, the data revealed that the students' learning process is facilitated by incidences of students creating the means and conditions that enable the continuity of the process. The emerging properties that facilitated learning include: cultivating social capital, renewal of expectations and aspirations, getting enticed and developing learning strategies.

Cultivating social capital included making friends easily in the kindergarten and school, having a good relationship with teachers by being helpful, neither afraid nor shy to initiate conversation with the teachers. These activities young students engaged in, enabled them to 
feel good about being in school. Social capital is a concept not commonly applied in children's context; however Leonard (2005) asserts that social networks and trust are important in promoting a sense of belonging and well-being. Albrecht (2004) argues that one of the indicators of social intelligence is the ability to interact successfully with others in various contexts.

Renewal of expectations and aspirations arose from either adverse or motivating incidences, at home or in the school, that resulted in the increased determination to make it through the learning process, as exemplified by this turn around conversation when a participant wanted to drop out of school due family turmoil, "Nanti kalau kita susah, kita berhenti kita lagi susah. Macam itu. Emak saya cakap... dia cakap kalau susah bagi la senang, jangan bagi susah lagi". Bandura (2001, p.7) states that "by being represented cognitively in the present, foreseeable future events are converted into current motivators and regulators of behaviour". Similarly, vision of a better life's situation in contrast to the present deficit state, kept the student motivated for school. Hope for a better future was renewed regularly by these incidences that facilitated school progress. The opposite would be hopelessness, as depicted by Freire (1992), "hopelessness is but hope that has lost its bearings" (p.8).

Getting enticed refers to what drew the students to school. These include getting enticed by the library due to serious reading habit. For example, a participant would rush out during recess, to the library instead of the school canteen to read story books, "I marked the page, and continued reading the next day". Getting enticed also arose from wanting to be with friends in the school, caring favourite teachers, achieving in favourite subjects, simple rewards from family or teachers, praise and acknowledgement of achievement which increased the students' self-esteem and self-worth and school appointments as class monitor, prefect or librarian. This was evident from a meeting with an Orang Asli mother and her ten-year old son who proudly revealed that son was a school prefect, and another girl in the vicinity proclaiming without prompt, "I am also [a] prefect!" Being a class monitor made a participant feel appreciated by the teachers, increased her good feeling and made her aware the need to be better and be more responsible, as well as increased her social standing among them. She recalled always being put in the limelight in class by her friends, "Hmm, selalu mereka kata ... Azizah [not her real name] lah jadi, Azizah lah jadi". This appointment in turn motivated her to be on top of the class, "Ya. Suka [jadi ketua kelas]. Kalau ketua kelas, mesti lah dia lebih baik daripada rakan sekelas yang lain, takkan lah dia nak lebih bawah". Pajares (2006), Brown and Marshall (2006), and Anderman (2010), elaborate the role of praise and acknowledging achievement in increasing self-esteem and selfworth, and strengthening self-efficacy belief.

Developing learning strategies helped students support their own learning. Participants shared indicators of how they used learning strategies that indicate a developing self-directed and self-regulated learning (Zimmerman, 1989; VanBriesen, 2010). The strategies included asking questions during lessons, "Tapi macam saya ni saya tak pandai sangat matematik. Jadi saya akan banyak tanya lah", actively seeking teachers for help during non-class hours, loud reading, completing homework, teaching friends and be taught by friends, and observing how senior students studied and maintained their learning routines. In summary, facilitating learning is about experiences and behaviours that promote, support and assist students in acquiring the skills and knowledge that sustained their learning progress, conceptualized as cultivating social capital, renewal of expectations and aspirations, getting enticed, and developing learning strategies.

\section{Accommodating Learning}

The concept of accommodation is analogous to that used in describing the adjustment of the lens of the eyes, at various distances, so as to keep the object in focus. In this context, the process of accommodating involves adapting, adjusting, reconciling, and the willingness to make the necessary changes, to keep learning in focus (Misnaton, Hamidah \& Marinah, 2015b). Accommodating learning is represented in: multiplicity of roles, accepting separation, changing vision of future self, accepting punishment, and making change.

Multiplicity of roles refers to the reality in which the students lived life within the multi-dimensional roles as child, sibling, and student. Each role had its attendant responsibilities, accommodated within the context of educating self. One participant, for instance, repeatedly recalled the feeling of 'a heavy burden on his shoulder' to fulfill the aspiration of his father who was a well-regarded Orang Asli community leader as well as an active parent in the school. The participant, the youngest of eleven children, accorded the only chance for the parents to see a child achieved the highest level of education. Daughters helped with household chores and cares of younger children that limited their learning time. However, the engaged student learned how to adjust their learning moments, and not letting the roles derailed them from achieving their aspirations and commitment.

Accepting separation refers to the ability to accept being left by the parents and be on their own such as when students had to leave the comfort of home for kindergartens. One participant related her first week kindergarten experience with her mother 'on board', staying in the classroom until her child accepted and adjusted herself to the new environment. In the hostel, the transition was moderated by the presence of older siblings, familiar friends from the same village, and relatives or family members serving in the hostel. Accepting separation was part of the accommodating process, in which students learned to accept changes and to make adjustments in new situations. Accepting separation involves the process of developing emotional independence (Albrecht, 2004; Zins, Bloodworth, Weissberg, \& Walberg, 2007), with the presence of moderating roles minimising the impact of separation.

Changing vision of future self reflects the changing ambitions of the students as they progressed through the schooling process. How ambition motivates action has been extensively discussed in the literature (Bandura, 2001; Pajares, 2006; Anderman, 2010). For instance, a participant wanted to be a lawyer at primary year 4 . When asked what she knew about being a lawyer, she explained that she was influenced by her father's stories and helplessness at the state of the Orang Asli affair, in particular about the loss of their earning land to a township development project. She perceived that being a lawyer would enable her to help defend and claim the rights of her father and the community. However, by primary year 6 , she wanted to be a police, influenced by a popular Bahasa Melayu television show. Later, she envisioned herself going to the university, after attending motivational talks organised by the school. Having ambition, a vision of the future self, is a property of facilitating learning, but changing ambitions is a process of accommodating learning based upon a more mature understanding and reflection of one's interest and capability, or perceived self-efficacy.

Accepting punishment is indicated throughout the narratives of these participants. The most common method of punishment was 'rotan (caning)' for behaviours such as not completing homework and misbehaving in school. The ability of the students to accept punishments, rationalizing them as part of the learning process, and taking the necessary steps to remedy their shortcomings, indicates the accommodative ability of these students. The opposite would be learning disengagement, missing school or extended absence leading to dropping out. The extreme was exemplified by the tragic incidence of the Sg Tohoi Primary School (News, 2015b). In the incidence, fear 
of perceived punishment due to breaking the hostel rule, resulted in 23 of 25 students who lived in the hostel running away, and the death of five students. Students, who were able to accept punishment, whether just or otherwise, successfully rode the emotional and physical pain that came with harsh punishment. This was the case of a participant who was slapped on the face by a teacher because she missed the extra class conducted in the afternoon due to the lack of a return transport. "Was it painful?" asked the researcher. "Yes. The teacher had a ring on her finger". As a result, she stayed back for the afternoon classes, walking alone for the 5 kilometer journey home, including through a lonely estate road, reaching home at dusk. In an ecological context, the concept 'resilience' is used to describe an environment that has the capacity to absorb disturbances, for self organization, and for learning and adaptation (Brand \& Jax, 2007). Similarly, accepting punishment, not succumbing, and moving forward are indicators of accommodating learning, as this poignant statement of a participant about his feeling after getting punished indicates, "Semua budak macam saya [tidak menangis bila dirotan]. Dia orang ni keraslah. Terima je. Orang kampung kan". Hunter (2012) asserts, resilience involves children displaying competent functioning despite exposure to high levels of risk or adversity.

Making change includes relocating, leaving the familiarity of home to access educational facility. For example, boarding in hostels enabled students to have better access to school and its educational provisions, guided learning environment, and to attend an intensive preparation for major public examinations. Hostels that provided boarding for both the primary and secondary school students also gave younger primary students glimpses of the secondary school life and expectation, as well as role models, thus paving the path to continuing education at the secondary level. The process of making the change was linked to how parents made the decision (Misnaton, Hamidah \& Marinah, 2015b), encouraging the students to accept and make the change.

The process of accommodating learning reflects the Orang Asli students' multiplicity of roles, making time for learning within the needs to fulfill the obligations and expectations of their other roles. Along the way, they accepted separation, adjusted vision of their future selves, accepted punishment and made changes that were necessary to maintain focus and their learning progress.

\section{Generating Learning}

Generating learning in this study is defined as making meaning and making sense of real life experience. It involves predicting and knowledge transfer, which is the ability to apply real life experience and prior learning to new situations. Wittrock (2010) argues that generating learning is about the abstract and the distinctive, concrete associations which the learner generates between his or her prior experience and the stimuli. The abstract refers to what is stored in the mind or past learning, whilst the distinctive refers to what is observed or required in the present state. The data revealed three properties in the students' generating learning process: Observing and making sense of real life adversities and success, role model, problem solving, and challenging boundaries and extending independence.

Observing and making sense of real life adversities and success is a distinct property that contributes to the student's generating learning process. The state of being poor provides the setting for initiation of learning (Kintrea, St Clair \& Houston, 2011). The realization that being poor is a problem and that it can be alleviated through better education and better job is generative learning. In making sense of her mother's words, a participant was forced to think about the consequences of not having an education. A participant recalled, "ermm... saya... err... paling ingat err... waktu kanak-kanak saya, mak saya selalu kata macam ni... ermm... kalau nanti tak belajar tak tahu membaca macam mana nanti nak keluar nak naik bas kalau tak tahu membaca nanti nak singgah mana-mana ke? tak tahu nak tekan ke? nak tekan [loceng] nak berhenti kat mana?' In this case, the mother's perspective of generative learning was about transferring her real life observation and experience to her daughter, whilst the daughter's perspective was making sense and making connections about the authenticity of her mother's statement.

Role model provides the stimulus for generative learning. Examples from the participants indicate that students generated learning by observing others and emulating their learning process. A participant who closely observed how his role model, a hostel senior, studied and organized his time recalled, "I made my own study time table after I saw his". Some students' ambitions were based upon teachers as role models, whilst others took up characters in television programs as models for their ambitions. Bandura (2001) refers to this process as observational learning through modeling.

Problem solving is indicated by the incidences of participants resolving their concerns and needs. For instance a participant generated her own learning moments by actively seeking teachers outside the class hours for help with school work. Another participant solved his desire for toys and games equipment by saving his pocket allowance, knowing his father could not afford to buy him the items. The participant who received a painful slap on her face for not attending the afternoon extra class decided that she would walk back despite the distance, alone and the late hour. Yet another participant, taking the role of the household head during the parents' absence, sold empty cans collected from a tourist site, to tide the family over the days when cash was short.

The generating learning process is indicated by how students challenged and extended the boundaries set by adults. As an example, a participant and her friends skipped the school van and walked back using an alternative route through the thick woods "kami redah semak (we headed into the tangles of underbrush)" and crossing a stream, in order to avoid the driver who they observed was taking drugs. They made the decision to avoid the perceived harm in the company of the driver. These are among incidences that reflect the capability of the students to make decision without adults' consultation, that challenged the boundaries and extended their independence through the ability to read situations and act accordingly, a concept referred to as situation awareness by Endsley (1995). 


\subsection{DISCUSSION}

Learners leading learning refers to the process of how successful Orang Asli students resolved their concerns that kept them in school. 'Successful' is about students that completed their primary schooling and beyond despite the deficit theorizing that explains the educational problems of the Orang Asli students. The underpinning strengths that enabled these students to lead their learning include hope and motivation (Freire, 1992; Carter-Wall \& Whitfield, 2012; Froiland, Peterson \& Davison, 2012), self-efficacy (Bandura, 1982; Pajares, 2006), agency (Bandura, 2001; Frost, 2006; MacBeath, 2012), self-concept and resilience (Brown \& Marshall, 2006; Hunter, 2012; Fletcha \& Soler, 2013) and continuous improvement (Deming, 1986). Hope and motivation were reflected through the Orang Asli students' vision of future selves, having respectable jobs and out of poverty. Self-efficacy was reflected through their actions and interactions that indicated a belief that they can do it. The agency was about taking ownership of their own learning and resolving the concerns that were theirs as well as what were expected of them. Self-concept and resilience was about springing back from adversities, and hardships, and not be subdued by challenges, whilst, continuous improvement was how the students find ways and means to better their learning process and achievement.

Implications for Practice: This study illuminates the possibilities of continuous improvement by reflecting upon the leading learning process of the successful Orang Asli students. Success is about sustained engagement and completing the initial schooling process upon which further learning engagement is built. Grounded upon the story of each participant, the emerging theory captures the strengths of these students within the limit of their social and economic capitals. Within the context of the entire study, this paper focuses only on how learners negotiated and lead their learning process. Thus, any implication for practice needs to take into consideration not only the strengths of the students as described in the findings, and building practice upon these strengths, also it must consider the systemic undercurrents that contributed to the strengths. These include the Orang Asli parental involvement and engagement described in Misnaton, Hamidah and Marinah (2015a), as well as how school led and scaffold the learning process. It is worth noting Riessman (1963), lamenting over fifty years ago, that, "Most approaches concerned with educating the disadvantaged child either overlook the 'positive' elements entirely, or merely mention in passing that there are positive features from which middle class groups might learn. But they do not spell out these strengths to any extent, and consequently they build educational programs almost exclusively around the weaknesses" (p.337). Thus reminded, educating the Orang Asli students will be enhanced by understanding the real life challenges and concerns of these students, and how they resolve their concerns.

Contributions to the Body of Knowledge: A grounded theory is judged by four criteria: fit, work, relevant and modifiable (Glaser \& Strauss, 1967; Hoda, 2011; Hakel, 2015). The theory fits when it matches the realities, in the eyes of the subjects, practitioners and researchers in the area of study; it works when it explains, predicts, and interprets what is happening; it is relevant if it fits and works thus offering explanations of the basic process in the substantive area, and the theory should be readily modifiable when new data present variations in emergent properties and categories. The method founders (Glaser and Strauss, 1967) emphasise: "Generating hypotheses requires evidence enough to establish a suggestion - not an excessive piling of evidence to establish a proof' (pp.39-40). Hence, this emerging theory of Orang Asli students leading learning lends itself to modification as new data emerges, also in congruence with the inductive realist view of truth (Hunt 2011). The theory extends the knowledge of how successful Orang Asli students negotiated their learning journey, and captures aspects that have not been sufficiently illuminated in the existing literature and discussion on the topic. A caveat, this short paper does not do justice to the extent of the Orang Students taking ownership and getting involved in their learning process. It only unveils an emerging theory of how Orang Asli students lead their learning process, making explicit their significance within their context of social, economic and human capital deficit. However, based upon current data, no claim is made to generalize the emerging theory beyond the context of this study.

\subsection{CONCLUSION}

The grounded theory of leading learning reveals how the Orang Asli students survived the deficit theorizing that surrounded them. Personal agency, taking ownership of their learning process, enabled the process to happen. The leading learning process was realised through the sub-processes of initialising, facilitating, accommodating and generating learning. Although this paper has focused on the leading learning process of the students, as captured through their voices, it must be highlighted that this alone is not sufficient to bring on better learning engagement and achievement among the Orang Asli students. A cohesive collective agential undertaking of other roles in the leading learning process is crucial. And this includes roles that are at home and in the community, in the school, the Government as well as Non-Government Organisations. Implications for practice includes for stakeholders to consider the Orang Asli's strengths, as well as their social and cultural capital in leading the learning of the community's children. Leveraging on their strengths and continuous improvement will contribute to the sustainability of the Orang Asli education, and the thriving of the community.

\section{Acknowledgements}

The first author acknowledges the continuous support, guidance and encouraging feedback of her supervisors in the research process. She also acknowledges the cooperation of the research participants for sharing their life stories in the learning journey and thanks Pusat Pengurusan dan Inovasi (Kod Penyelidikan: 2013-0180-107-02), Sultan Idris Education University, for the Grant that partially supports this study. 


\section{References}

Albrecht, A. (2004). Social Intelligence Theory. Retrieved from https://www.karlalbrecht.com/siprofile/siprofiletheory.htm

Anderman, E. C. (2010). Reflections on Wittrock's Generative Model Of Learning: A Motivation Perspective. Educational Psychologist, 45(1), 55-60. DOI: $10.1080 / 00461520903433620$

Bandura, A. (1982). Self-Efficacy Mechanism In Human Agency. American Psychologist, 37(2), 122-147.

Bandura, A. (2001). Social Cognitive theory: An agentic perspective. Annual Review of Psychology, 52, 1-26.

Berryman, M., Carr-Stewart, S., Maggie Kovach, M., Cornelia Laliberté, C., Sharon Meyer, S., Merasty, B., Anne Sloboda, A., Stelmach, B. \& Steeves, L. (2014). Seeking their voices: Improving Indigenous Student Learning Outcomes For The Saskatchewan Ministry Of Education. Saskatchewan Instructional Development and Research Unit (SIDRU), Faculty of Education, University of Regina. Retrieved from http://aerc.usask.ca/research-projects-planningactivities/Seeking\%20Their\%20Voices_Nov\%202014.pdf

Bezzina, M. (2012). Paying Attention to Moral Purpose in Leading Learning: Lessons from the Leaders Transforming Learning and Learners Project. Educational Management Administration Leadership, 40(2), 248-271. DOI: 10.1177/1741143211427979

Bishop, R., Berryman, M., Tiakiwai, S. \& Richardson, C. (2003). Te Kotahitanga: The Experiences Of Year 9 And 10 Maori Students In Mainstream Classrooms. Ministry of Education, New Zealand.

Bishop, R., Berryman, M., Wearmouth, J., Peter, M. \& Clapham, S. (2011). Te Kotahitanga: Maintaining, Replicating And Sustaining Change: Report For Phase 3 and 4 schools 2007-2010. Ministry of Education New Zealand. Retrieved from http://www.educationcounts.govt.nz/_data/assets/pdf_file/0007/105838/988_TeKotahitanga.pdf

Brand, F. S. \& K. Jax, K. (2007). Focusing the Meaning(S) Of Resilience: Resilience As A Descriptive Concept And A Boundary Object. Ecology and Society 12(1). 23. [online] URL: http://www.ecologyandsociety.org/voll2/iss1/art23/

Brown, J. D. \& Marshall, M. A. (2006). The Three Faces Of Self-Esteem. In M. Kernis (Ed.), Self-Esteem: Issues And Answers, 4-9. New York: Psychology Press.

Carter-Wall, C. \& Whitfield, G. (2012). The Role Of Aspirations, Attitudes And Behaviours In Closing The Educational Attainment Gap. York: JRF. Retrieved from http://www.nationalnumeracy.org.uk/sites/default/files/education-achievement-poverty-summary.pdf

Deming, W. E. (1986). Out of the crisis. Cambridge: Cambridge University Press.

Edo, J. (2012). Pendidikan Orang Asli: Harapan dan Peluang. In Ramle Abdullah, Mohammed Hafis Amat Simin, Azlina Abdullah \& Zurina Mansor (Eds.), Pendidikan Orang Asli dalam arus perdana. Kuala Terengganu: Penerbit Universiti Sultan Zainal Abidin, 31-34.

Endsley, M. (1995). Toward a Theory Of Situation Awareness In Dynamic Systems. Human Factors. The Journal of the Human Factors and Ergonomics Society, 37(1), 32-64. DOI: 10.1518/001872095779049543

Flecha, R. \& Soler, M. (2013). Turning Difficulties Into Possibilities: Engaging Roma Families And Students In School Through Dialogic Learning. Cambridge Journal of Education, 43(4), 451-465. DOI: 10.1080/0305764X.2013.819068

Ford, M. (2013). Achievement Gaps In Australia: What NAPLAN Reveals About Education Inequality in Australia. Race Ethnicity and Education, 16(1), 80-102. DOI: $10.1080 / 13613324.2011 .645570$

Fraser, M. (2005). Dorothy Howard and the folklore of Australian Children. Retrieved from http://museumvictoria.com.au/pages/6148/play-and-folklore-issue46jul2005.pdf

Freire, P. (1992). Pedagogy Of Hope: Reliving Pedagogy Of The Oppressed. New York: Continuum.

Froiland, J. M., Peterson, A. \& Davison, M. L. (2012). The Long Term Effects Of Early Parent Involvement And Parent Expectation in the USA. School of Psychology International, 34(1), 33-50. DOI: 10.1177/0143034312454361

Frost, D. (2006). The Concept Of 'Agency' In Leadership For Learning. Leading \& Managing, 12(2), 19-28. Retrieved from https://www. educ.cam.ac.uk/centres/lf1/projects/pastprojects/DF\%20art\%20Agency.pdf

Gill, T. (2012). Traditional Outdoor Games: Why Do They Matter? Retrieved from http://rethinkingchildhood.com/2012/08/22/traditional-games/

Glaser, B. (2012). No Preconception: The Dictum. Grounded Theory Review: An International Journal (Online). Retrieved from http:// groundedtheoryreview.com/2012/11/28/no-preconception-the-dictum/.

Glaser, B. G. \& Holton, J. (2004). Remodeling Grounded Theory. Forum Qualitative Sozialforschung / Forum: Qualitative Social Research, 5(2), Art. 4, Para 1-80. Retrieved from http://nbn-resolving.de/urn:nbn:de:0114-fqs040245.

Glaser, B. G. \& Strauss, A. L. (1967). The Discovery Of Grounded Theory. Chicago, IL: Aldane (7th paperback printing 2012).

Guenther, J. (2015). Culturally And Contextually Responsive Schools: What Are They And Why Do They Matter? Remote Education Systems (RES) Project, Lecture Number 7, New England, Australia. Retrieved from https://www.academia.edu/15343360/Culturally_and_contextually_ responsive schools what are they and why do they matter.

Hakel, K. (2015). Oscillating Between Conservation And Investment: A Grounded Theory Of Students' Strategies For Optimizing Personal Resources. The Grounded Theory Review, 14(1), 11-25. Retrieved from http://groundedtheoryreview.com.

Helme, S. \& Lamb, S. (2011). Closing the School Completion Gap For Indigenous Students. Canberra: Australian Institute of Health and Welfare \& Melbourne: Australian Institute of Family Studies. Retrieved from http://www.aihw.gov.au/uploadedFiles/ClosingTheGap/Content/Publications/2011/ctgc-rs06.pdf

Hoda, R. (2011). Self-Organising Agile Teams: A Grounded Theory. PhD Thesis. Victoria University of Wellington, N. Zealand. Retrieved on 31 March 2014, from http://researcharchive.vuw.ac.nz/xmlui/bitstream/handle/10063/1617/thesis.pdf?sequence=2.

Hunt, S. D. (2011). Theory Status, Inductive Realism, And Approximate Truth: No Miracles, No Charades. International Studies in the Philosophy of Science, 25(2), 159-178. DOI: 10.1080/02698595.2011.574858.

Hunter, C. (2012). Is Resilience Still A Useful Concept When Working With Children And Young People? Child Family Community Australia, CFCA Paper No. 2, Australian Institute of Family Studies. Retrieved from https://aifs.gov.au/cfca/publications/resilience-still-useful-concept-when-working-child/export

JAKOA (2015a). Buletin Perangkaan KKLW 2013. Retrieved from http://www.rurallink.gov.my/web/guest/hal-ehwal-orang-asli.

JAKOA (2015b). Portal Rasmi Jabatan Kemajuan Orang Asli (JAKOA). Retrieved from http://www.jakoa.gov.my/orang-asli/info-orang-asli/suku-kaumbangsa/

Johari Talib \& Nazri Muslim (2007). Bagaimana kanak-kanak Orang Asli gagal di sekolah? Jurnal Pengajian Umum, 8, 51-75. Retrieved from http://www.myjurnal.my/public/issue-view.php?id=3576\&journal_id=307\#.

Kamaruddin, K. \& Jusoh, O. (2008). Educational Policy And Opportunities Of Orang Asli: A Study On Indigenous People In Malaysia. The Journal of Human Resource and Adult Learning, 4(1), 86-97.

Kintrea, K., St Clair, R. \& Houston, M. (2011). The Influence Of Parents, Places And Poverty On Educational Attitudes. York: Joseph Rowntree Foundation. Retrieved from www.jrf.org.uk

Ladson-Billings, G. (1995). But That's Just Good Teaching! The Case for Culturally Relevant Pedagogy. Theory into Practice, 34(3), 159-165. Retrieved from http://dsb1.ca/aboriginal/pdfs/the_case_for_culturally_relevant_pedagogy.pdf.

Leonard, M. (2005). Children, Childhood And Social Capital: Exploring The Links. Sociology, 39(4), 605-622. DOI: 10.1177/0038038505052490.

Lye, T. P. (2011). A History Of Orang Asli Studies: Landmarks And Generations. Kajian Malaysia, 29(1), 23-52. Retrieved from http://web.usm.my/km.

MacBeath, J. (2012). Leadership for Learning: Concepts, Principles And Practice. Retrieved http://www.educ.cam.ac.uk/centres/lfl/projects/ghana/resources/LfL-Concepts_Principles_Practices_cc_1.pdf

Misnaton Rabahi (2001). A Case Study Of Leadership In A Self-Managing School: A Quality Management Perspective. (With specific Reference To An Independent School In the U.K.). Unpublished MA Dissertation. University of Wolverhampton, U. Kingdom.

Misnaton Rabahi, Hamidah Yusof \& Marinah Awang (2015a). Model of hope: Leading learning among the Indigenous Orang Asli students. Paper presented at the $2^{\text {nd }}$ International Conference on Multidisciplinary Trends in Academic Research, 29-30 September 2015, Bangkok, Thailand.

Misnaton Rabahi, Hamidah Yusof \& Marinah Awang (2015b). Leading Learning: A Grounded Theory Perspective Of Orang Asli Parental Involvement And Engagement. Procedia - Social and Behavioral Sciences, 211 (2015), 94-103. DOI: 10.1016/j.sbspro.2015.11.015. 
MOE (2013). Malaysia Education Blueprint 2013-2025: Preschool To Post-Secondary Education. Putrajaya: Ministry of Education (MOE) Malaysia. Retrieved from http://www.moe.gov.my/cms/upload_files/articlefile/2013/articlefile_file_003108.pdf.

MOENZ (2013). Ka hikitia: Accelerating Success 2013-2017. The Maori Education Strategy, Ministry of Education New Zealand (MOENZ). Retrieved from http://www.education.govt.nz/assets/Documents/Ministry/Strategies-and-policies/Ka-Hikitia/KaHikitiaAcceleratingSuccessEnglish.pdf.

Mohd Asri Mohd Noor (2012). Advancing the Orang Asli through Malaysia's Clusters of Excellence Policy. Journal of International and Comparative Education, 1(2), 90-103. Retrieved from http://e-journal.um.edu.my/filebank/published_article/4576/mohd\%20noor.pdf.

Nelson, S. (2002). Learn-Ed Nations Inventory-A Tool For Improving Schools With American Indian And Alaska Native Students. Northwest Regional Educational Laboratory, USA. Retrieved from educationnortwest.org/web_send/197.

News (2015a). SK Tohoi tragedy: Education Ministry To Set Up Special Committee. Astro Awani Network SB (11 October, 2015). Retrieved from http://english.astroawani.com/malaysia-news/sk-tohoi-tragedy-education-ministry-set-special-committee-76060.

News (2015b). Kisah Sebenar Tragedy Kehilangan Murid Orang Asli SK Tohoi. Astro Awani Network SB (15 October 2015). Retrieved from http://www.astroawani.com/berita-malaysia/kisah-sebenar-tragedi-kehilangan-murid-orang-asli-sk-tohoi-76520.

News (2015c). Bajet 2016: Dana RM300 Juta Tumpu Kesejahteraan Orang Asli. Mstar (23 Oktober 2015). Retrieved from http://www.mstar.com.my/berita/beritasemasa/2015/10/23/dana-orang-asli/.

Norwaliza A Wahab, Ramlee B Mustapha \& Abdul Razaq Ahmad (2016). The Roles of Administrators in Aboriginal Schools: A Case Study in a Malaysian State. International Journal of Social Science and Humanity, 6(5), 370-374. DOI: 10.7763/IJSSH.2016.V6.674.

Oberg, A., Blades, D. \& Thom, J. S. (2007). Untying A Dreamcatcher: Coming To Understand Possibilities For Teaching Students of Aboriginal inheritance. Educational Studies, 42(2), 111-139. DOI: 10.1080/00131940701513185.

Pajares, F. (2006). Self-efficacy during childhood and adolescence: implication for teachers and parents. In F. Pajares and T. Urdan (Eds.), Self-efficacy Beliefs of Adolescents (pp.339-367). Information Age Publishing. Retrieved from http://sites.education.uky.edu/motivation/files/2013/08/18464-SelfEfficacy_During_Childhood_and_Adolescence-Implications_for_Teachers_and_Parents.pdf.

Ramlah Jantan \& Aslina Ahmad (2013). Literacy and Psychosocial Problems Among Aboriginal Students In Primary School in Cameron Highlands (Malaysia). International Journal of Education and Research, 1(9), 1-8. Retrieved from http://www.ijern.com/journal/September-2013/27.pdf.

Ramle Abdullah, Wan Hasmah Wan Mamat, W. A. Amir Zal \& Asmawi Mohamad Ibrahim (2013). Teaching and learning problems of the Orang Asli education: students' perspective. Asian Social Science, 9(12), 118-124. DOI:10.5539/ass.v9n12p118.

Ramlee Mustapha (2013). Attributes that affect self-efficacy and career development of Orang Asli youth in Peninsular Malaysia. Journal of Southeast Asian Education, 6(1), 1-24. Retrieved from http://www.academia.edu/7555756.

Riessman, F. (1963). The Culturally Deprived Child: A New View. Research in Review, February 1963, 337-347. Retrieved from http://www.ascd.org/ASCD/pdf/journals/ed_lead/el_196302_riessman.pdf.

Robinson, R., Molenda, M., \& Rezabek, L. (2008). Facilitating learning. In A. Januszewski, \& M . Molenda (Eds.), Educational technology: A definition with commentary (pp. 15-48). New York \& London: Lawrence Erlbaum Associates. Retrieved from http://www.aect.org/publications/ EducationalTechnology/ER5861X_C002.pdf.

Rosenberg, J. (1996). A History Lesson In Folklore In Education: Dorothy Howard. Retrieved from http://files.eric.ed.gov/fulltext/ED394890.pdf.

Sharifah Md Nor, Samsilah Roslan, Aminuddin Mohamed, Kamaruddin Hj Abu Hassan, Mohamad Azhar Mat Ali \& Jaimah Abdul Manaf (2011). Dropout prevention initiatives for Malaysian Indigenous Orang Asli Children. The International Journal on School Disaffection, 8(1), 42-56.

SUHAKAM (2014). SUHAKAM Annual Report 2014. The Human Rights Commission of Malaysia, Kuala Lumpur. Retrieved from https://docs.google.com/file/d/0B6FQ7SONa3PRUG1nc25yRGV3TlU/preview?pli=1.

SUHAKAM (2015). Need for equal footing in education. The Human Rights Commision of Malaysia (SUHAKAM). The New Straits Times Online (18 October 2015). Retrieved from http://www.nst.com.my/news/2015/10/need-equal-footing-education.

Tarmiji Masron, Fujimaki Masami \& Norhasimah Ismail (2013). Orang Asli in Peninsular Malaysia: Population, Spatial Distribution and Socio-Economic Condition. Ritsumeikan Journal of Social Sciences and Humanities, 6, 75-115. Retrieved from http://www.ritsumei.ac.jp/acd/re/k-rsc/hss/book/ki_en_006.html

Valencia, R. R. (1997). The Evolution of Deficit Thinking: Educational Thought and Practice. The Stanford Series on Education and Public Policy.

Valencia, R. R. (2010). Dismantling Contemporary Deficit Thinking: Educational Thought And Practices. New York: Routledge.

VanBriesen, J. M. (2010). Self-directed learning. Retrieved from https://www.nae.edu/File.aspx?id=37803.

Wan Afizi Wan Hanafi, Shaharuddin Ahmad \& Noraziah Ali (2014). Faktor Budaya Dan Persekitaran Dalam Prestasi Pendidikan Anak Orang Asli Malaysia: Kajian kes di Kelantan. Geografia: Malaysian Journal of Society and Space, 10(5), 107-122. Retrieved from http://www.ukm.my/geografia/ images/upload/10x.geografia-okt14-wan\%20afizi-edam.pdf.

Wittrock, M. C. (2010). Learning as a Generative Process. Educational Psychologist, 45(1), 40-45. DOI: 10.1080/00461520903433554 (Reprinted From The Article Originally Published in 1974. Educational Psychologist, 11(2), 87-95).

Zimmerman, B. J. (1989). A Social Cognitive View Of Self-Regulated Academic Learning. Journal of Educational Psychology, 81(3), 329-339. http://dx.doi.org/10.1037/0022-0663.81.3.329.

Zins, J. E., Bloodworth, M. R., Weissberg, R. P., \& Walberg, H. J. (2007). The Scientific Base Linking Social And Emotional Learning To School Success. Journal of Educational and Psychological Consultation, 17(2-3), 191-210. DOI: 10.1080/10474410701413145. 